\title{
Field Photographs of Geomorphic Features in the Lake Karakul Region, Eastern Pamirs
}

\section{東パミール・カラクル湖地域の地形的な特徵に関する写真資料}

\author{
Tetsuya KOMATSU* \\ 小松 哲也*
}

Key words : Lake Karakul, Pamir, paleoshoreline, glaciation, weathering キーワード : カラクル湖, パミール, 旧汀線, 水河作用, 風化

\begin{abstract}
要旨
カラクル湖（ca. $39^{\circ} \mathrm{N}$, ca. $73^{\circ} 25^{\prime} \mathrm{E}$ ）は，東パミールの北東部，標高 $3,915 \mathrm{~m}$ に位置する閉塞湖である。その湖岸には，過 去の湖面変動と氷河変動による地形・堆積物が非常に良く残されている。これらを発達史的な観点から研究することは, 東パミールの第四紀後期以降の古環境変遷の理解に貢献すると考えられる。そこで, 本稿では, そうした研究を行う上で 重要な意味を持つ地形・堆積物の特徵, ならびにそれらの露出年代の指標となる風化礫の特徴の二点について取り上げ, それらの写真を研究資料として提示した。
\end{abstract}

\section{I . Introduction}

Lake Karakul (ca. $39^{\circ} \mathrm{N}$, ca. $73^{\circ} 25^{\prime} \mathrm{E}$ ) is a closed-basin lake situated in the northeastern Pamirs (Fig. 1). It is located at an altitude of $3,915 \mathrm{~m}$ a.s.l. and has an area of $380 \mathrm{~km}^{2}$. Paleoshoreline landforms and glacial landforms can be observed in the coastal area of the lake. Reconstruction of lakelevel fluctuations and glacial history on the basis of the classification of these landforms is crucial for discussing the long-term climate changes of the arid eastern Pamirs, where the present mean annual precipitation is below $100 \mathrm{~mm}$ (UNEP, 2002). However, little is known about the distribution and classification of the landforms. In this paper, I present photographs (see Fig. 2 for localities) of geomorphic evidence of paleolakes and glaciation and rock-weathering features, which are one of the best indicators of the age of glacial landforms and deposits. I describe the glacial and lacustrine terrace landforms from the chronological viewpoint elsewhere.

\section{II . Paleoshoreline landforms and related sediments}

Well-developed paleoshoreline landforms can be observed, particularly in the outwash fans in the northern region of the Karakul closed-basin (Photo 1). On the basis of the paleoshoreline developments on the outwash fans, paleoshoreline landforms can be classified into four groups: $\mathrm{H}$ Shorelines, M Shorelines, L Shorelines, and LL Shorelines (in the descending order of height). The highest level of the H, M, L, and LL Shorelines is $205 \mathrm{~m}$ (4,120 m a.s.l.), $85 \mathrm{~m}$ (4,000 $\mathrm{m}$ a.s.1.), $35 \mathrm{~m}$ (3,950 $\mathrm{m}$ a.s.1.), and $10 \mathrm{~m}$ (3,925 $\mathrm{m}$ a.s.l.), respectively, above the present lake level (3,915 $\mathrm{m}$ a.s.l.). These four paleoshoreline groups include some distinct paleoshoreline landforms (Photos 1 and 2) and sediments (Photos 3 and 4) commonly observed around Lake Karakul.

\footnotetext{
*Graduate School of Environmental Science, Hokkaido University, Japan／北海道大学大学院環境科学院・院生
} 


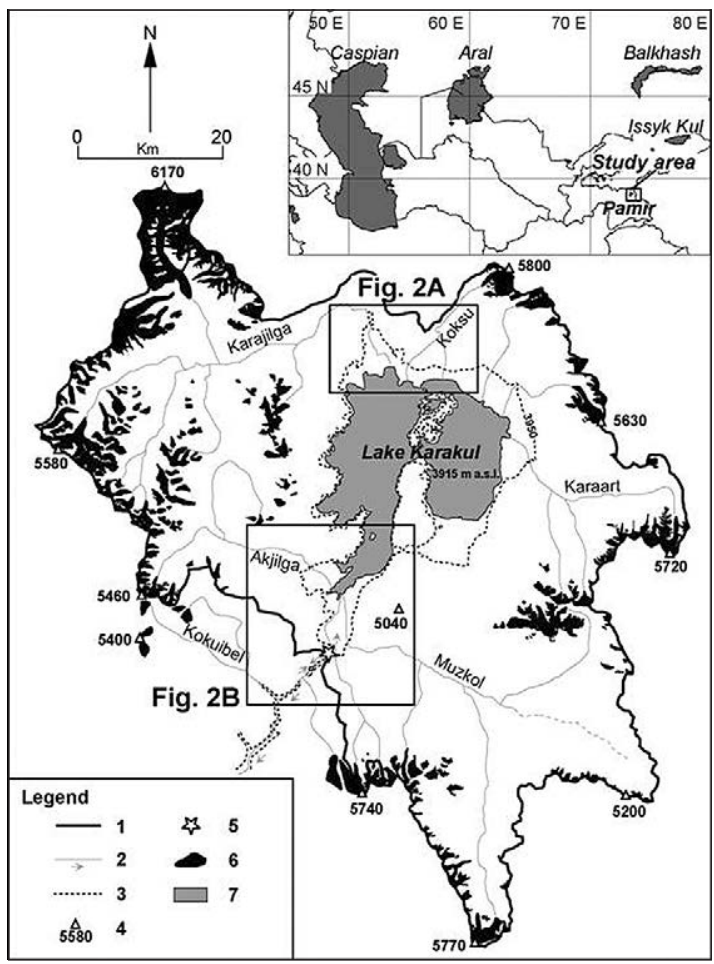

Fig. 1. Lake Karakul. 1: Divide of the Karakul closed-basin, 2: Main stream and flow direction, 3: Contour line (3,950 $\mathrm{m}$ a.s.l.), 4: Main peak and its altitude, 5: Threshold of the Karakul closed-basin, 6: Glacier and perennial snow patch, and 7: Lake. Detailed observations were conducted in the regions indicated by the black boxes.
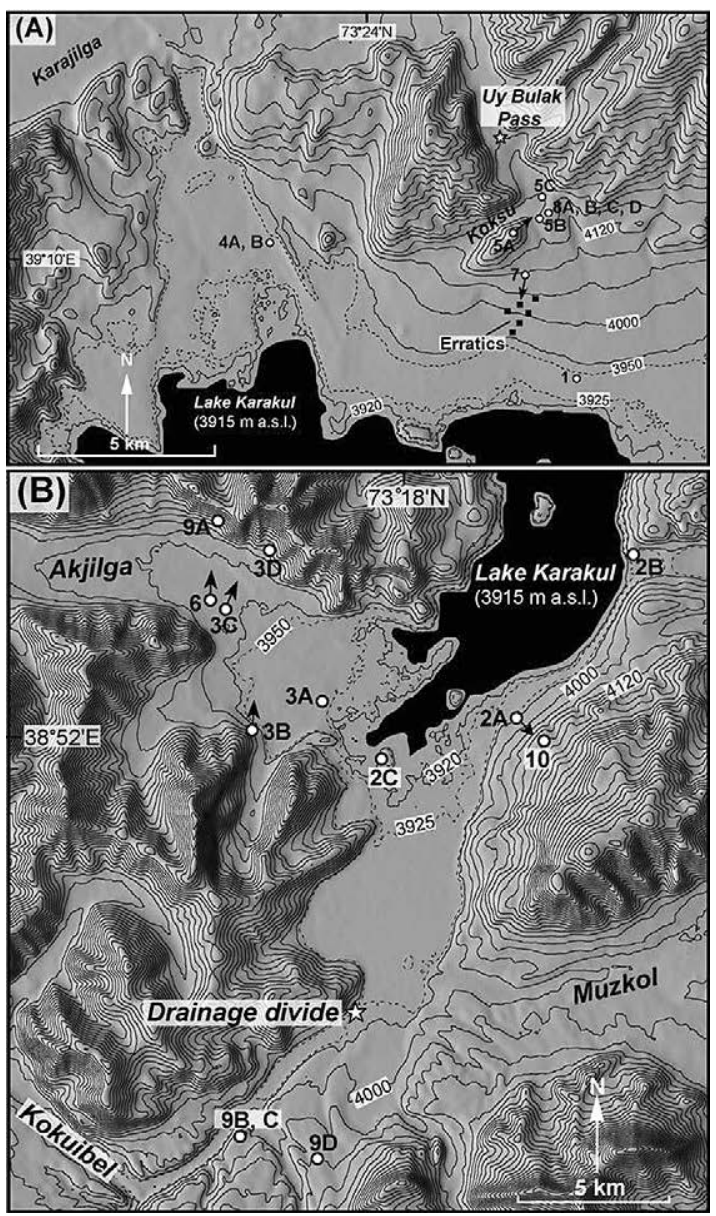

Fig. 2. Locations of observation points in and around the Karakul closed-basin. (A) Northern area and (B) southeastern area. Counter lines on the base maps were drawn using the data obtained from the Shuttle Radar Topographic Mission-3 (SRTM-3 DEM) in 2000.

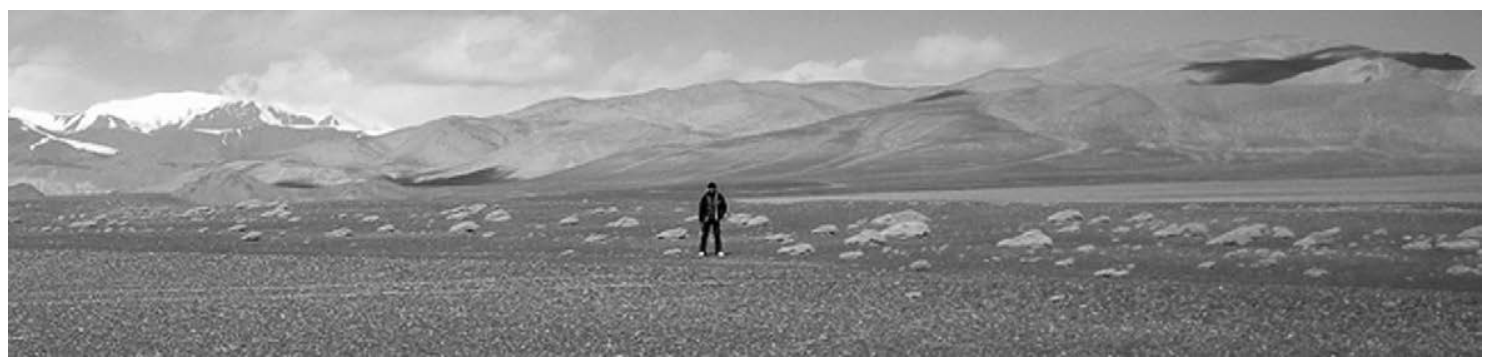

Photo 1. Typical view of wave-cut terrace with paleoshoreline altitude of 3,940 $\mathrm{m}$ a.s.l. on the northern outwash fans. There are approximately 60 such landforms and they can be observed from 3,916 m a.s.l. to $4,120 \mathrm{~m}$ a.s.l. 


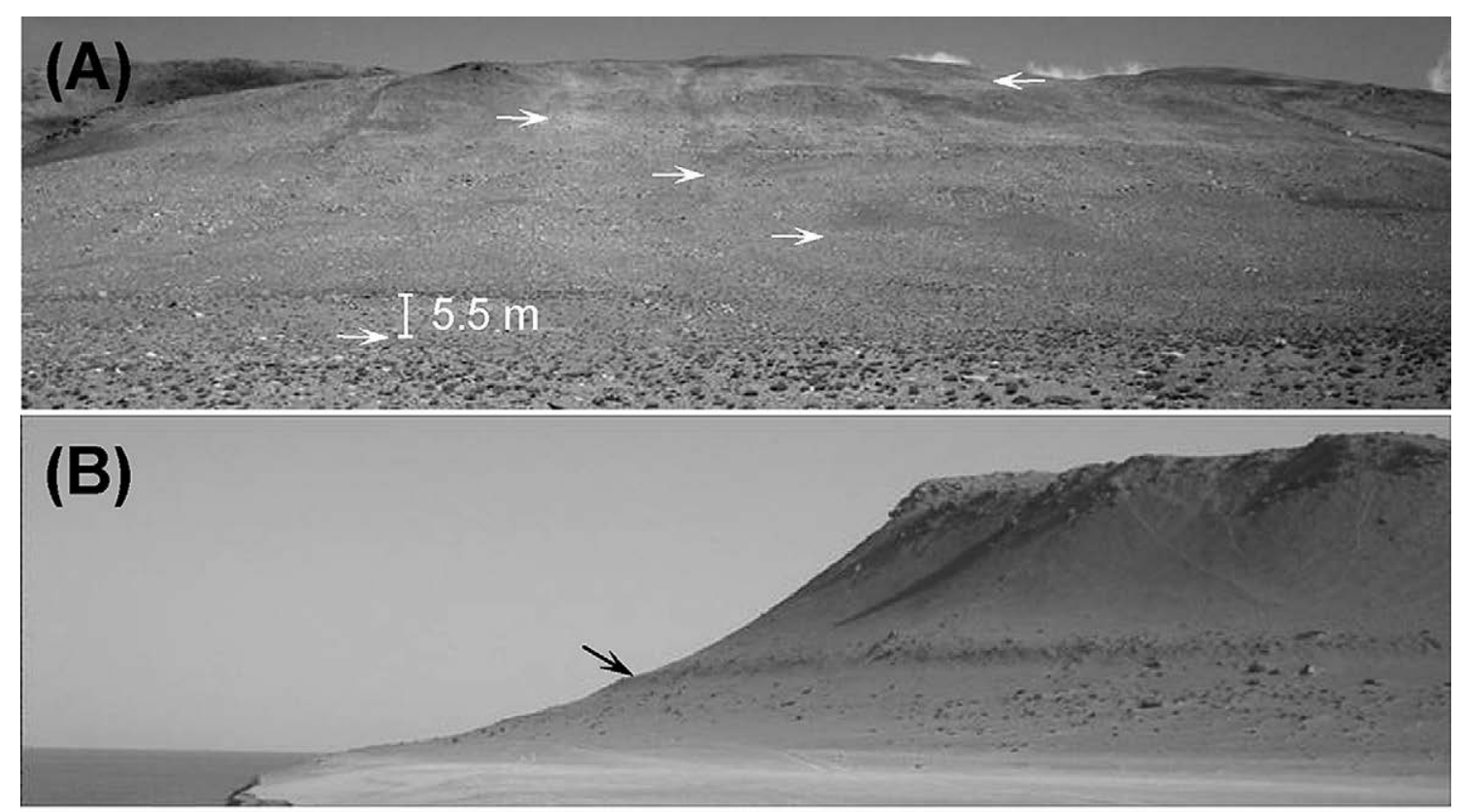

\section{(C)}

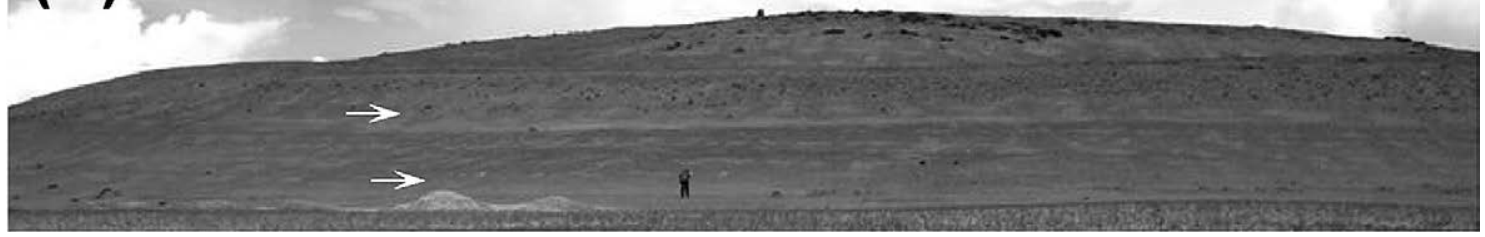

Photo 2. Distinct paleoshoreline landforms on hill slopes. (A) Five abrasion terraces associated with $\mathrm{H}$ Shorelines and M Shorelines can be clearly identified. The paleoshoreline altitudes of the five terraces are approximately 4,120 $\mathrm{m}$ a.s.l., 4,090 $\mathrm{m}$ a.s.l., 4,080 $\mathrm{m}$ a.s.l., 4,050 $\mathrm{m}$ a.s.l., and 4,000 $\mathrm{m}$ a.s.l. (B) The highest paleoshoreline of L Shorelines (3,950 $\mathrm{m}$ a.s.l.). (C) Two wave-cut benches belonging to the $\mathrm{L}$ and LL Shorelines. The paleoshoreline altitudes of these terraces are approximately 3,930 $\mathrm{m}$ a.s.l. and $3,925 \mathrm{~m}$ a.s.l.

\section{Glacial landforms and deposits}

Considering the relation between glacial landforms and paleoshoreline landforms (Photos 5 and 6), the glacial stages in the Lake Karakul region can be classified into four stages: GH, GM, GL, and GLL (in the descending order). On the basis of the glacial and lacustrine sediments (Photos 3B and 6), it can be inferred that the maximum advance of each glacial stage was synchronous with the highest stand of each paleolake. Both the timing of the glacial advance and the paleolake highstand aid in speculating the origin of the large boulders present on the submerged outwash fan, as shown in Photo 7.

\section{Weathering features}

In the Lake Karakul region, granite boulders frequently exhibit distinctive cavernous forms such as tafoni (Photo 8). On the other hand, rocks with schistosity (e.g. phyllites and slates) are characterized by shattered surfaces in addition to cavernous surfaces (Photo 9).

Photo 10 shows salt accumulation beneath weathered gravels. This fact suggests that salt 
weathering is one of the major weathering processes in this region.
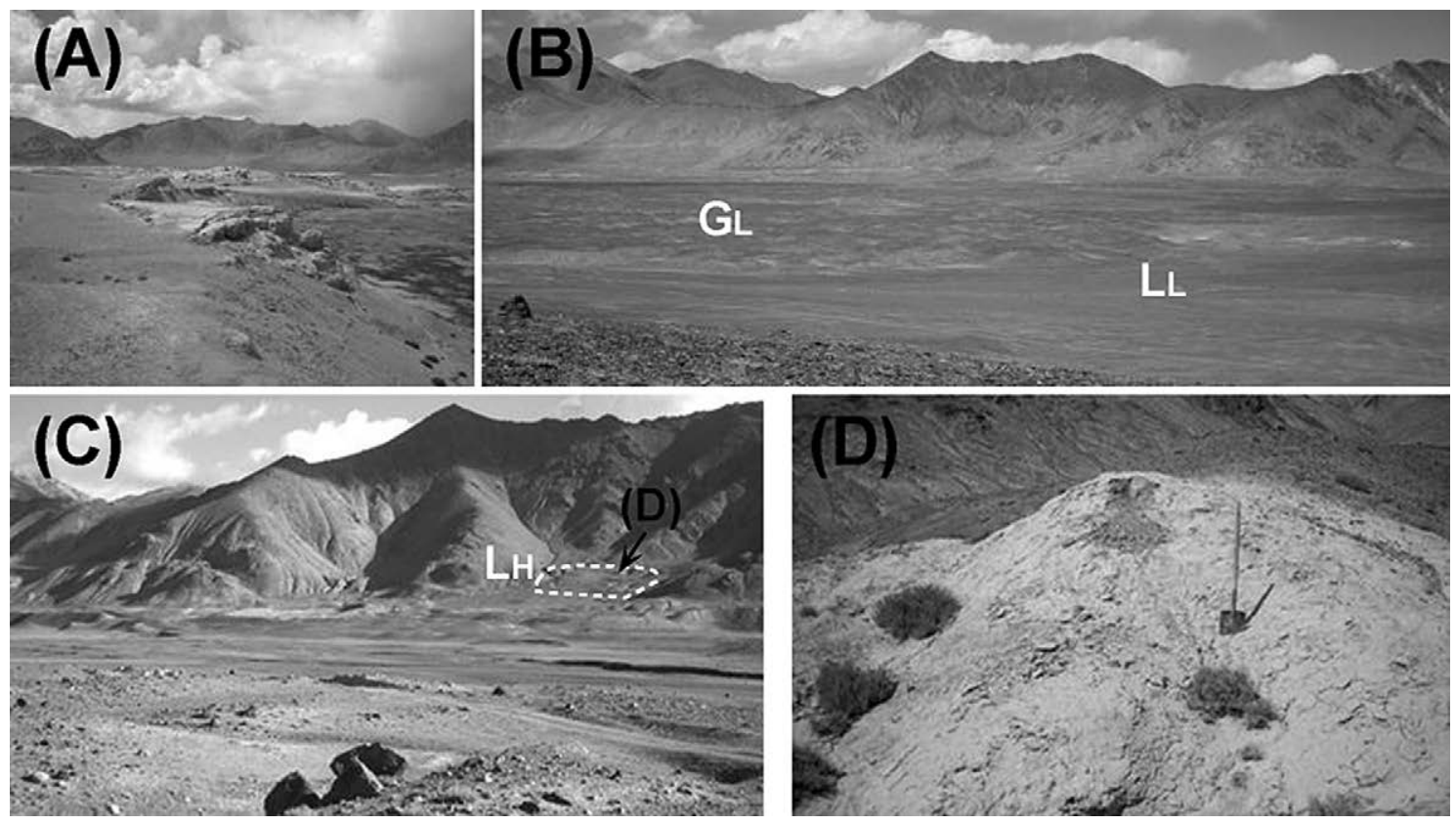

Photo 3. Lacustrine terraces in the lower reach of the Akjilga valley at two different levels. (A) The lower lacustrine terrace ( $\mathrm{LL}_{\mathrm{L}}$ ) rising $10 \mathrm{~m}$ to $25 \mathrm{~m}$ above the present riverbed. (B) Lacustrine terrace shown in (A) succeeded by a hummocky terminal moraine $\left(\mathrm{G}_{\mathrm{L}}\right) 3,950 \mathrm{~m}$ a.s.l. This fact suggests that the maximum glacial advance period was synchronous with the period of paleolake stand at the highest level of L Shorelines. (C) The higher lacustrine terrace $\left(\mathrm{LH}_{\mathrm{H}}\right)$ is at an altitude of 4,120 $\mathrm{m}$ a.s.l. This lacustrine terrace was formed in association with the highest stand of the H Shorelines. (D) Close view of the lacustrine sediments at $4,120 \mathrm{~m}$ a.s.l.
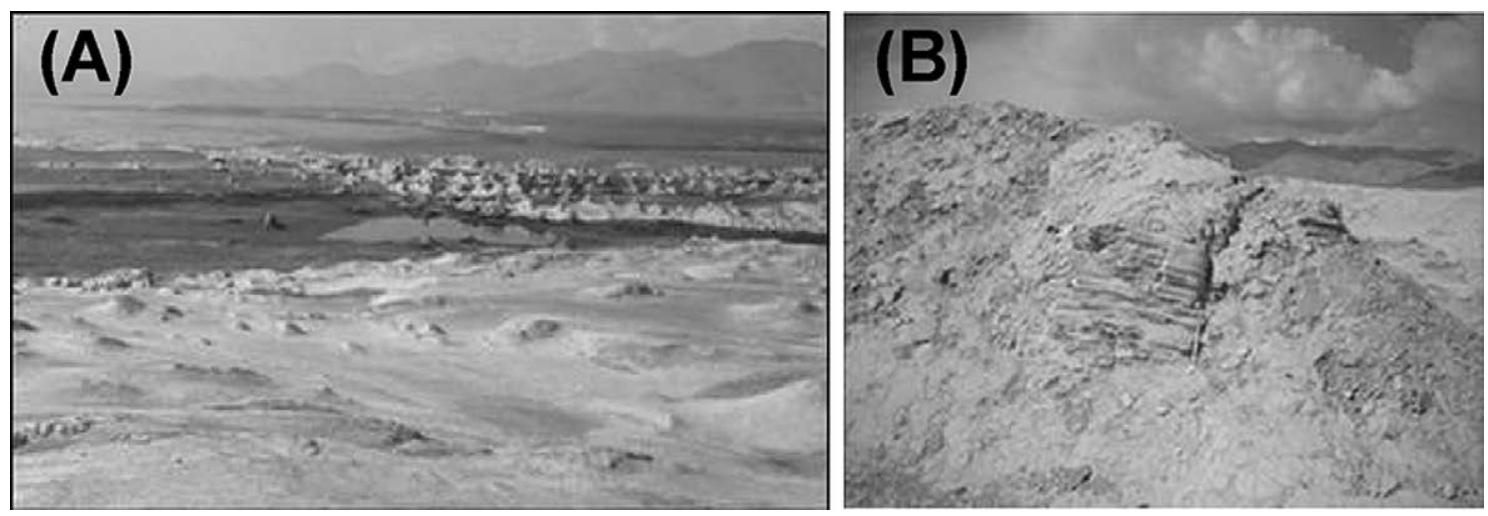

Photo 4. Lacustrine terrace distributed in the lower Karajilga valley. (A) Photo of the lacustrine terrace showing hummocky surfaces formed by deflation. This lacustrine terrace is distributed up to 3,950 $\mathrm{m}$ a.s.l. and is succeeded by a terminal moraine. (B) Close view of the stratified lacustrine sediments. 

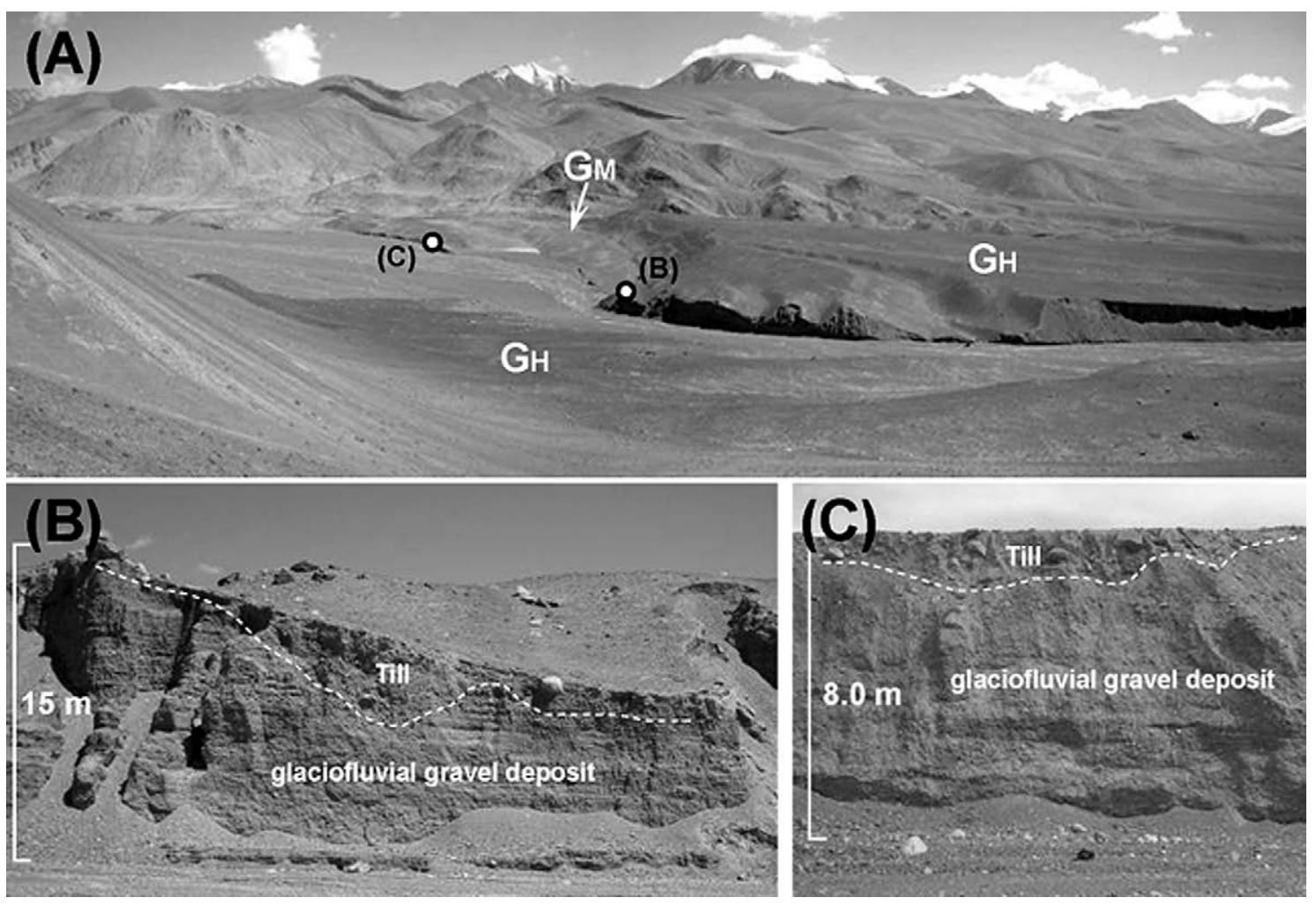

Photo 5. Glacial landforms in the lower reaches of the Koksu valley. (A) GH terminal moraines overlaying the oldest outwash terrace (F1), which is carved by H Shorelines. The GM terminal moraines erode the GH moraines. (B) Outcrop of $\mathrm{GH}_{\mathrm{H}}$ moraines. (C) Outcrop of $\mathrm{G}_{\mathrm{M}}$ moraines. The stratigraphy observed in the $\mathrm{GH}_{\mathrm{H}}$ and $\mathrm{G}_{\mathrm{m}}$ moraine deposits indicates that the submerged outwash fans in this area were formed during each glacial advance stage.

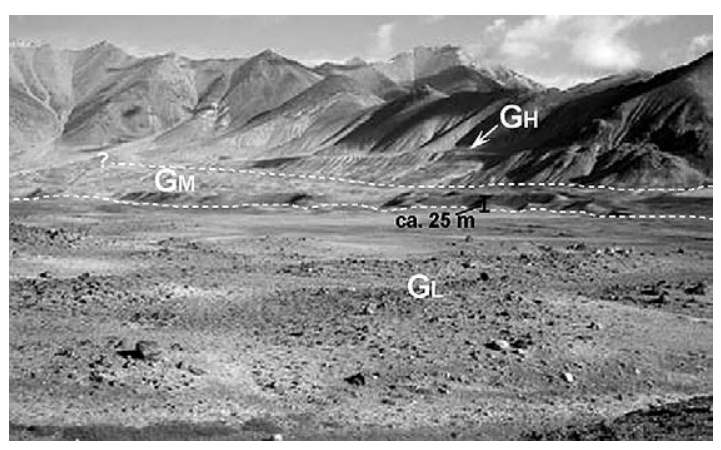

Photo 6. Glacial landforms in the lower Akjilga valley: the highest moraine ridges of the $\mathrm{G}_{\mathrm{H}}, \mathrm{G}_{\mathrm{M}}$, and $\mathrm{G}_{\mathrm{L}}$ stages are located $80-100 \mathrm{~m}, 40-65 \mathrm{~m}$, and $25 \mathrm{~m}$ above the valley floor, respectively. The outermost moraines of the GL moraines and $\mathrm{GH}_{\mathrm{H}}$ moraines are succeeded by lacustrine terraces at two levels, namely, 3,950 $\mathrm{m}$ a.s.l. and 4,120 $\mathrm{m}$ a.s.l., as shown in Photo 3. On the other hand, lacustrine terraces related to Gm moraines do not exist. 


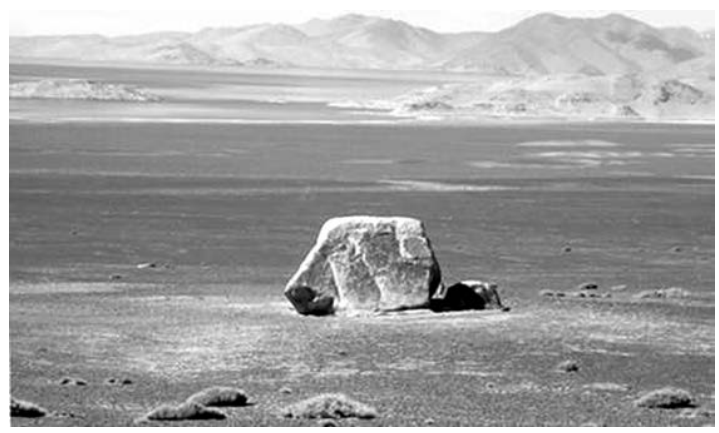

Photo 7. A $270-\mathrm{cm}-$ high granite boulder observed in the northern outwash fan at 4,015 $\mathrm{m}$ a.s.1. $\left(39^{\circ} 09^{\prime} 24.1^{\prime \prime} \mathrm{N}\right.$, $73^{\circ} 26^{\prime} 58.2^{\prime \prime E}$ ). It should be noted that such large boulders are distributed only on the surface of the F1 outwash (see photo 5), as shown in Fig. 2. Some of these boulders can be found at altitudes above the highest level of the M Shorelines (4,000 $\mathrm{m}$ a.s.l.). From these facts and the geomorphology of this area, it is speculated that the boulders on the outwash fan might have been carried by icebergs originating from the Karajilga valley during the paleolake highstand associated with the $\mathrm{H}$ Shorelines.
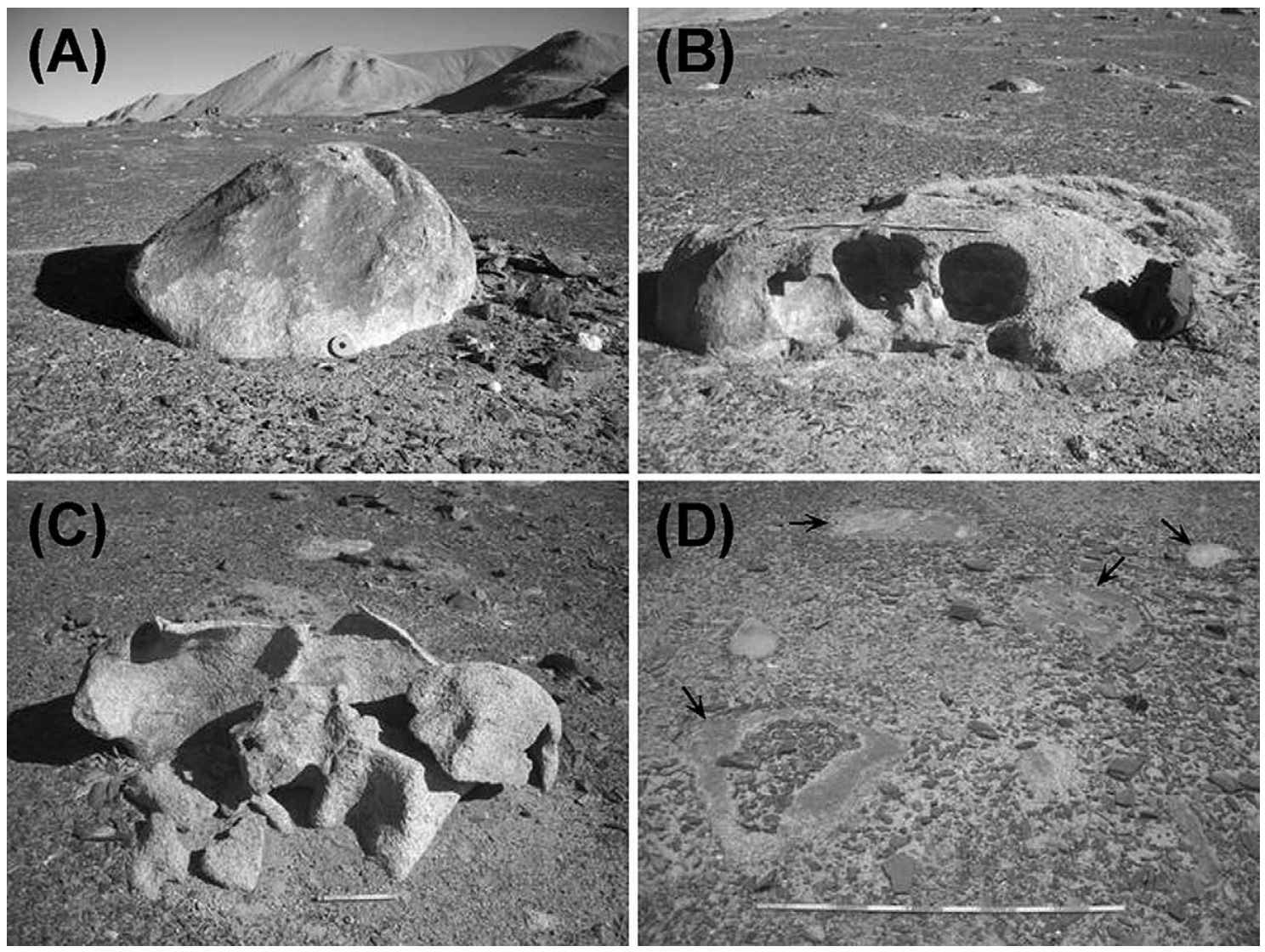

Photo 8. Different degrees of cavernous weathering of granitic boulders on the glacial till. (A) A boulder that has undergone cavernous weathering to a slight extent. (Scale is $30 \mathrm{~cm}$ long.) (B) A boulder showing strong cavernous weathering. (Scale is $100 \mathrm{~cm}$ long.) (C) A disintegrated boulder that has undergone intensive cavernous weathering. (Scale is $20 \mathrm{~cm}$ long.) (D) Boulders weathered to the surface level. (Scale is $100 \mathrm{~cm}$ long.) 

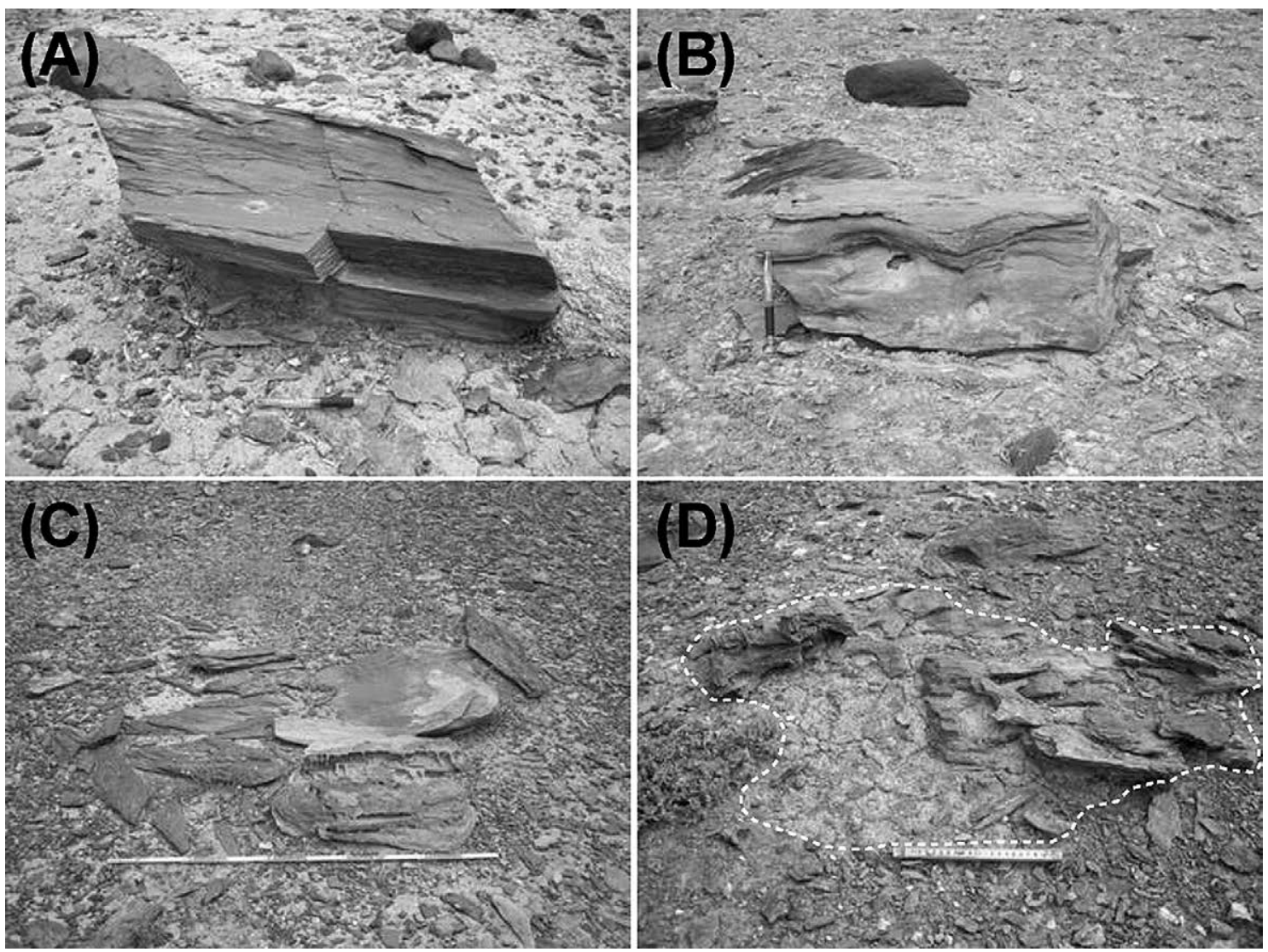

Photo 9. Different degrees of physical weathering of moraine gravels with schistosity like phyllites and slates. (A) Boulder with slight shattering features. (Pen is $15 \mathrm{~cm}$ long.) (B) Boulder with cavernous weathering features in addition to shattering features. (Pen is $15 \mathrm{~cm}$ long.) (C) Disintegrated gravels. Some of the scattered fragments exhibit cavernous weathering. (Scale is $100 \mathrm{~cm}$ long.) (D) Gravels with advanced granular disintegration. It should be noted that most of the scattered fragments are completely weathered to sand grains. The dashed line shows the original outline of boulder as inferred from weathered materials. (Scale is $20 \mathrm{~cm}$ long.)

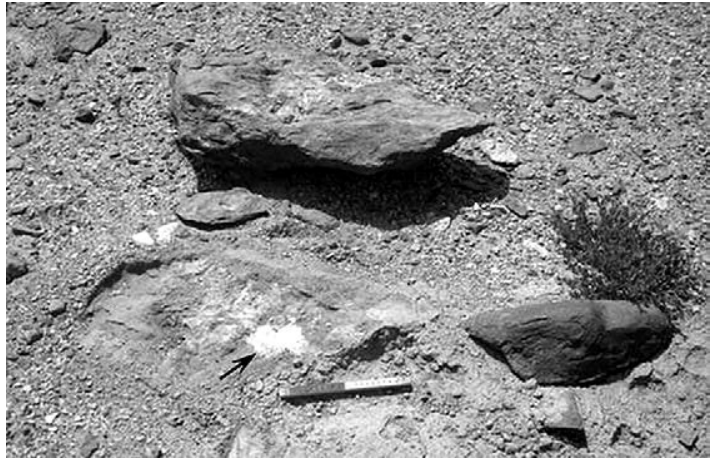

Photo 10. White salt encrustation beneath overturned surface gravels on the southern hill slope at $4,160 \mathrm{~m}$ a.s.l. The scale is $20 \mathrm{~cm}$ long.

\section{Reference}

UNEP (2002): Vital maps and graphics on climate change, Tajikistan, http://enrin.grida.no/htmls/tadjik/ vitalgraphics/eng/html/climate.htm. 